Bruce J. Summers is a senior vice president and chief financial officer at the Federal Reserve Bank of Richmond. R. Alton Gilbert is a vice president and banking advisor at the Federal Reserve Bank of St. Louis. Mary C. Lohmann provided research assistance.

\section{Clearing and Settlement of U.S. Dollar Payments: Back to the Future?}

\section{Bruce J. Summers and R. Alton Gilbert}

The Federal Reserve System was formed in 1914. Wide dissatisfaction with routinely expensive and slow settlement of interregional payments, as well as occasional disruptions of the payments system caused by banking panics, are among the factors that led to its creation. Accordingly, an important purpose for creating the Federal Reserve to serve as the nation's central bank was to enhance the efficiency and improve the stability of the nation's payments system.

At the time of the formation of the Federal Reserve, the paper check was the principle means of making payment. The Federal Reserve attempted to fulfill its mandate for improving the check-collection system by providing banks with a national check-collection service. ${ }^{1}$ Since it was the only institution with a nationwide network of banking offices and settlement accounts for banks, it had an advantage in interregional check collection. Over time, the Reserve Banks added new payment services to exploit the advantages of new technology: wire transfer of reserves, a book-entry service for safekeeping and electronically transferring ownership of government securities, and the automated clearinghouse, designed as an electronic alternative to checks.

The share of U.S. dollar payments processed through the Federal Reserve Banks began declining in 1980, when the Reserve Banks began charging for payment services, as required by the M onetary Control Act. This declining share, for both smalland large-dollar payments, appears to represent a major shift in the operation of the U.S. dollar payments system. Our paper examines the implications of this shift for the Federal Reserve's ability to fulfill its mandate to safeguard the stability and efficiency of the payments system. In particular, we examine whether the problems that existed in the payments system prior to 1914 will at some time reappear as the Fed's operational role declines. It is important to consider whether the nation's payments system has changed in ways that make Reserve Bank services less essential for dealing with the problems that have beset it in times past, and what the future role of the Federal Reserve Banks should be as payment processing systems continue to evolve.

The following section examines the operation of the payments system prior to the formation of the Federal Reserve, focusing on aspects of the system that were considered defects by advocates of a central bank. Subsequent sections establish a conceptual framework for our analysis and describe the payment services offered by the Reserve Banks and trends in their share of the total volume and value of U.S. dollar payments processed each year. The article then discusses reasons for the declining Reserve Bank share of payment processing and the implications of these trends for the payments system.

\section{PROBLEMS WITH THE PAYMENTS SYSTEM PRIOR TO THE FORMATION OF THE FEDERAL RESERVE}

An analysis of the importance of Reserve Bank payment services for the banking industry in the United States
1 For convenience, depository
institutions are called banks. 
requires a review of some banking history. ${ }^{2}$ By the mid-1850s, the dollar value of U.S. bank deposits exceeded that of banknotes, and the value of transactions settled by check exceeded the value of transactions settled by banknote. This growth in check transactions required a system for clearing a large number of checks among banks. Before the introduction of Federal Reserve services, commercial banks cleared checks drawn upon other local banks by channeling them through local clearinghouses or delivering them directly to the local banks for payment. Typically, local checks could be collected quickly and at par.

Collecting checks drawn on banks outside a given community involved more time and expense. When checks were presented directly to paying banks at their place of business, the banks were required by law to pay the face value of the checks. Banking law did, however, permit banks to pay less than the face amount of checks submitted for collection by indirect means, such as through the mail. The rationale for this deduction from the face amount, called an exchange charge, was that remitting payment could involve certain costs, including the cost of transporting coin or bank notes from the paying bank to the collecting bank. Delays were another expense to collecting banks, in addition to exchange charges. Under banking law, a bank that received checks through the mail became the collecting agent for the bank that had sent them and was therefore responsible for obtaining payment from itself. As a result, paying banks often remitted funds to collecting banks several days after receiving checks through the mail.

Despite the rational e for exchange charges, many bankers considered them a basic defect in the operation of the payments system. Prior to the formation of the Federal Reserve System, there were several major proposals and attempts by bankers to eliminate exchange charges. Opposition to exchange charges was most common among bankers in the larger cities, where banks generally paid for checks drawn on accounts of their depositors at par, through local clearinghouses. The banks that imposed exchange charges generally were relatively small and located in more isolated areas.

Collecting banks attempted to avoid these delays and exchange charges by using the services of correspondent banks. Often depository banks (the banks of first deposit) sent checks drawn on banks outside their communities to their correspondent banks. The correspondents would then send the checks to other banks with offices near the paying banks, which, in turn, would present the checks to the paying banks over the counter. In this system of collection through correspondents, depository banks might receive less than the face amount of the checks, but more than if the checks were sent directly to paying banks. The correspondents would split the collection fee (the difference between the face value of the checks and the amount credited to the demand accounts of the depository banks) with the other banks that had assisted them in getting the checks to the paying banks. In some arrangements, the correspondents would credit the demand accounts of depository banks for the full amount of the checks being collected but would require the depository banks to hold large demand balances as a form of compensation for this service. Under either arrangement, it was competition among correspondent banks that tended to reduce the costs of collecting interregional checks.

The process of collecting checks through correspondents as a means of avoiding exchange charges led to some notorious cases of checks passing through the offices of many banks and traveling over very long distances, relative to the actual distance between the depository bank and the paying bank. Many of the resulting delays and operating expenses could have been avoided through more direct collection channels. Competition among correspondent banks, however, led to substantially reduced levels of exchange charges over time (Spahr, 1926, pp. 102-3). 
Although exchange charges declined substantially over time, many bankers continued to view them as a fundamental defect in the operation of the nation's payments system. Congress responded to calls for reform by giving the Federal Reserve a mandate to improve the efficiency of the payments system, and the Federal Reserve responded by establishing a national network of offices for collecting checks. Because the Federal Reserve Act forbids the Reserve Banks from paying exchange charges to banks, the Reserve Banks established the practice of accepting for deposit only those checks drawn upon banks that had agreed to pay the Reserve Banks at par. ${ }^{3}$ Although the Federal Reserve was not granted legal authority over the exchange charges set by individual banks, its dominant operational role in check collection eventually made collection at par (zero exchange charges) a national standard for the banking industry.

Another problem with the operation of the payments system prior to the formation of the Federal Reserve in 1914 was the occasional disruption of the payments system caused by banking panics. When events caused depositors to lose confidence in the safety of their deposits, they demanded payment in gold coin, banknotes or greenbacks. ${ }^{4}$ Banks located outside the major financial centers maintained large shares of their cash assets in deposits with major banks in the financial centers, particularly N ew York City, and they tended to respond to depositors' substantial cash withdrawals by drawing down deposits with these banks. Sprague (1910), in his analysis of banking panics in the national banking era, emphasized that the concentration of bankers' deposits in a small number of banks in N ew York City made the banking system vulnerable to disruption.

Bankers attempted to cope with panics through cooperative arrangements implemented through their local clearinghouses. During normal times, activities of the clearinghouses were limited largely to check clearing and settlement: Banks deposited gold with the clearinghouses and received certificates that served as claims on the gold; they cleared checks through the clearinghouses and settled their net positions with clearinghouse certificates. At times of relatively high depositor demand for gold and currency (banknotes and greenbacks), the clearinghouses created additional certificates for interbank settlement, called loan certificates. Banks that borrowed these additional certificates from their clearinghouse pledged some of their commercial loans or other securities to the clearinghouse as collateral. This process of accepting bank loans as collateral and issuing loan certificates had the effect of increasing the monetary base. M embers of the clearinghouse could use the gold and currency in their vaults to meet the demand of their depositors without concern that they would have insufficient cash assets to cover net debit positions at the clearinghouse.

On several occasions after clearinghouses had created loan certificates for their members, clearinghouse members also suspended currency payments to their depositors. While creation of loan certificates helped banks respond to unusually large demands for currency, the loan certificates were used primarily to settle interbank positions with the clearinghouse. Banks were obligated to pay their depositors gold or currency but did not al ways do so when their inventories were inadequate to meet the demand of their depositors. ${ }^{5}$ Instead, during some general suspensions of currency payments to depositors, banks paid their depositors small-denomination loan certificates, issued by their clearinghouses, which served as substitutes for currency in emergency situations (Andrew, 1908).

Before the creation of the Fed, when banks in major financial centers suspended currency payments to depositors, major disruptions in the payments system resulted. There is evidence that these suspensions, each of which lasted only one or two months during the period from the Civil War through 1914, seriously disrupted economic activity, including
${ }^{3}$ Under the Federal Reserve's Regulation J, which governs the collection of checks and other items by Reserve Banks, an "item" does not include a check that cannot be collected at par. Further, the Reserve Banks are required to accept cash and other items at par.

${ }^{4}$ After passage of federal banking legislation in the 1860s, the paper currency in circulation comprised notes issued by national banks and greenbacks ( fiat currency issued by the United States Treasury). Because national banks were required to back their notes with U.S. Treasury securities deposited with the Treasury Department, the public considered national bank notes as safe as gold coins, even during banking panics.

${ }^{5}$ Some have criticized the national banks in New York City for suspending currency payments when they still had large amounts of gold and currency in their vaults. These critics maintain that the banks were too concerned about meeting their legal reserve requirement- vault cash (gold and currency) that equalled or exceeded 25 percent of their deposits - rather than using all of the cash in their vaults to meet demands of their depositors (Dewald, 1972). 
interregional and foreign trade, particularly in 1873 (Sprague, 1910, pp. 71-82) and in 1893 (pp. 119-210).

The Federal Reserve System, modeled after the clearinghouses of the period, was authorized to deal with panics by increasing bank reserves through discount window loans. ${ }^{6}$ Its creators assumed that government sanction would lessen the impact of banking panics, and an experience in 1914, just before the Fed was created, may support this assumption. The outbreak of war in Europe triggered runs on U.S. banks. However, the AldrichVreeland Act of 1908 had authorized clearinghouses to put into circulation emergency issues of national banknotes, which had been printed and stored for such an event. Roberds (1995), who finds that the real economic impact of the panic of 1914 was smaller than that of prior panics, argues that the difference can be attributed to government sanction for the emergency issuance of national banknotes.

\section{CONCEPTUAL FRAM EWORK}

This section describes some concepts that are fundamental to understanding the operation of the payments system and the role of the Reserve Banks.

\section{Clearing and Settlement}

In describing Reserve Bank services, it is useful to distinguish between two processes: the clearing of payments and interbank settlement of payment obligations. M ost Reserve Bank services combine the clearing and settlement functions, although the Reserve Banks also offer interbank settlement services, with the clearing of payments among the banks performed through private channels. The implications for the payments system of declining Reserve Bank operations depend on which function of the Fed is affected more: clearing or settlement.

Clearing comprises three main steps: processing payment instruments, delivering them to paying banks, and calculating interbank payment obligations. Settlement involves discharging the payment obligations. To illustrate the distinction between these two functions, consider the clearing and settlement of checks among banks that are members of a clearinghouse. Banks rely on the clearinghouse to perform the clearing function when they exchange checks drawn on each other. Then the clearinghouse calculates the multilaterally netted payment obligations due to and due from each clearinghouse participant. Banks participating in the clearinghouse have various options for settling these obligations. Members of the clearinghouse can agree to settle using cash or more likely the deposit liabilities of a private bank, which might also be a member of the clearinghouse, or through another institution. Alternatively, settlement could be accomplished through the transfer of reserves maintained at the Reserve Banks. Using Federal Reserve Bank liabilities to achieve interbank settlement is important from a public policy perspective for at least two reasons: First, reliance on Reserve Bank liabilities contributes to the robustness of settlement arrangements and reduces the moral hazard that might result if all providers of payment services relied upon a small number of large commercial banks as settlement intermediaries. Second, it is by offering Fedwire and net settlement services to clearinghouses that the Federal Reserve is able to exert an indirect form of supervisory influence on the safety and soundness of private clearing arrangements, since the Federal Reserve lacks statutory authority over the operations of clearinghouses. (See Juncker, Summers, and Young, 1991.)

\section{Network Effects}

According to the literature on industrial organization, an industry has network effects if the value of a service to a customer depends on the number of other customers using the service. These network effects have important implications for industry structure and competitive behavior ( see Economides and White, 1994; Katz and Shapiro, 1994).

Because the payments system has some of the characteristics of a network 
industry, it is also important to consider the role of network effects in its operation. To illustrate, consider the value of membership in a check clearinghouse to banks with offices in a community where several banks conduct business. Initially, each bank sends payment instruments to each of the other banks demanding payment in currency for checks that are presented. Then, two of the banks in the community decide that they can reduce their operating costs-and the risk of having currency lost or stolen-by arranging for their messengers to meet at an intermediate point and exchange checks. The two banks agree to settle among themselves by debiting and crediting balances they hold with each other, rather than moving currency about the community.

This clearing and settlement arrangement would be even more efficient if these two banks were to get a third bank to join them, clearing checks among the three banks under rules they agree to adopt as a clearinghouse. In the same way, this clearinghouse would be even more valuable for its members if additional banks joined. If these network effects are strong enough, there will be one check clearinghouse in the community, and all banks with offices there will be members.

In an industry with network effects, the first entity to develop a network has an advantage over later entrants. To be successful in developing a rival network, the new entity must convince many participants to switch to its network simultaneously, since the value of a network to each participant depends on the number of other participants using the network. Many years ago, the Reserve Banks developed a dominant network for interregional check clearing, which gave the Federal Reserve leverage over the operation of the payments system. Even if some banks did not like the rules under which the Reserve Banks offered payment services or the process innovations favored by the Fed, those with a lot of interregional checks to clear found it advantageous to use the Fed's clearing and settlement network.
One alternative, of course, to using the Fed's network is to develop a private network for interregional check clearing. Developing such an alternative would have been especially difficult prior to 1980, however, when the Reserve Banks provided payment services to member banks only, free of explicit charge. Prior to passage of the M onetary Control Act of 1980, which required the Reserve Banks to charge for their services, almost all of the banks that cleared a high volume of interregional checks were members of the Federal Reserve System. A rival to the Fed for interregional check clearing would have had to convince banks to pay a positive charge per check (compared to a zero charge per item in the Fed's system) or withdraw from Fed membership and rely on the new private system. Once the Reserve Banks began assessing checkclearing charges and requiring all banks to maintain reserves, the private systems for check clearing became more viable al ternatives to the clearinghouse services of the Reserve Banks.

Industries with strong network effects also tend to be highly concentrated. If private payments networks were to supplant the role of the Reserve Banks, this development would raise antitrust issues with respect to access to the payments system. Thus, the declining role of the Reserve Banks in processing payments and the development of private systems for check clearing compel us to examine the issues of competition and monopolies in the nation's payments system.

\section{FEDERAL RESERVE BANK SERVICES}

This section reviews the laws and Federal Reserve policies that govern the activities of Reserve Banks as providers of payment services. It also describes the principal payment and payment-related services provided by the Reserve Banks. The appendix describes the payment services of the Reserve Banks in more detail and discusses major changes in the services over the years. 


\section{MCA GUIDELINES FOR PRICING BANK SERVICES}

The following section of the M onetary Control Act (MCA) specified guidelines for the pricing of Reserve Bank services:

"Over the long run, fees shall be established on the basis of all direct and indirect costs actually incurred in providing the Federal Reserve services priced, including interest on items credited prior to actual collection, overhead, and an allocation of imputed costs which takes into account the taxes that would have been paid and the return on capital that would have been provided had the services been furnished by a private business firm, except that the pricing principles shall give due regard to competitive factors and the provision of an adequate level of such services nationwide."

Thus, the basis for the Federal Reserve's setting the prices of its payment services below levels as specified in this section of the MCA is inadequate competition in markets for payment services or an inadequate level of services in at least some regions of the nation.

${ }^{7}$ Operating circulars are detailed instructions concerning particular banking services, including account services, payment services, and the discount window. Some apply uniformly to all 12 Reserve Banks, while others apply to the services of individual Reserve Banks.

8 For an analysis of the value of "free" Reserve Bank payment services to member banks relative to the opportunity cost of their required reserves, see Gilbert (1977).

\section{Background}

The Reserve Banks function as bankers' banks: Banks that use the Fed's payment services maintain reserve balances at the Reserve Banks and have access to credit from the Fed. All transactions cleared through the Reserve Banks are settled on a gross basis; that is, the value of each transaction is settled through a debit or credit to a bank's reserve account. Occasionally, debits and credits resulting from use of the Fed's payment services can cause a bank to miss its target for reserves, or they can cause a negative reserve balance. Reserve Banks lend reserves to banks that are temporarily short of funds, including both intraday credit (daylight overdrafts) and overnight credit (discount window loans or overnight overdrafts). The Reserve Banks also serve as fiscal agents to the federal government by providing payment services to the United States Treasury and to various other government agencies.

Reserve Banks have special privileges and powers as suppliers of payment services. For example, they have legal authority to present checks for same-day settlement later in the day than do private banks.
Further, Reserve Banks have access to privileged supervisory information concerning the condition of banks, which they may use to protect themselves from losses in providing payment services and related credit. In addition, they can create reserves to meet the liquidity needs of banks.

\section{Law and Policy Governing Reserve Bank Services}

The Reserve Banks provide payment services under the authority of the Federal Reserve Act, as amended over the years. The terms and conditions under which they provide services are governed by regulations of the Board of Governors and implemented through Reserve Bank operating circulars. ${ }^{7}$

The Monetary Control Act of 1980 (MCA) was a watershed for the Reserve Banks as providers of payment services. Prior to passage of the MCA, the member banks in the Federal Reserve shouldered a required reserve burden which they could satisfy through only two forms of nonearning assets: deposits held in accounts with the Reserve Banks and vault cash. Banks that were not members of the Fed system were not burdened by this requirement. Provision of "free" payment services by the Reserve Banks was viewed as an offset to the reserve requirement burden. ${ }^{8}$ But the MCA changed all that:

1. It extended the reserve requirements of the Federal Reserve to all depository institutions.

2. It granted all depository institutions access to the discount window and to Reserve Bank services.

\section{It required the Reserve Banks to} charge explicit fees for their services.

Under the MCA, the Reserve Banks' revenue from fees on their payment services must, over the long run, equal or exceed the cost of providing the services plus a markup to reflect the tax rates and profit rates of private-sector firms (see shaded box on MCA guidelines). Thus, the MCA subjects the Reserve Banks to 
market discipline similar to that faced by commercial firms: Reserve Banks must provide services efficiently, price them competitively, and meet the market's standards for quality services. Further, they must be careful to gauge the profitability of new service offerings.

Since passage of the MCA, the Federal Reserve Board has also issued guidelines that specify in more detail the conditions under which Reserve Banks may provide payment services. The guidelines issued in June 1981, state that "the System should be prepared to remove itself from the provision of those services that can be supplied more efficiently by the private sector, unless there are overriding public interest considerations for maintenance of an operational presence by the System" (Federal Reserve Regulatory Service 7-191). Further, the Board of Governors' M ay 1990 policy statement on the role of the Federal Reserve in the payments system sets additional conditions to be met before the Reserve Banks may offer new payment services: "the service should be one that other providers alone cannot be expected to provide with reasonable effectiveness, scope, and equity" (Federal Reserve Regulatory Service 7-145.1). Thus, the MCA, together with Federal Reserve Board policies, establishes market-oriented criteria for determining whether and how the Reserve Banks are to provide services.

While these formal and explicit conditions under which Reserve Banks may continue to offer existing services or enter new payment markets were devel oped after passage of the MCA, earlier decisions by the Board of Governors suggest something about the Federal Reserve's philosophy in providing services. In particular, there is evidence that, well before the MCA, the Board wished to proscribe Reserve Bank involvement in the processing of new types of payment instruments. In the second half of the 1960s, for example, the Federal Reserve came under some pressure from bankers to adapt its check-clearing services to handle the processing of credit card sales slips. For a variety of reasons, including concern over the public sector's shouldering significant new costs for handling a quasi-payment instrument, the Board decided to deny the credit card industry access to the check clearing infrastructure of the Reserve Banks (Brimmer, 1967). Accordingly, the Reserve Banks play no role in processing credit card transactions. Instead, a private-sector infrastructure has grown up to support this important component of the payments system.

In contrast to this decision on processing credit card slips, the Board agreed, at approximately the same time, to requests from bankers that the Reserve Banks provide operational support for the nascent automated clearinghouse $(\mathrm{ACH})$ as a method of processing payments. The $\mathrm{ACH}$ represented a desirable al ternative to checks that would require new automation systems and significant start-up costs. Because these start-up costs would have been difficult for the private sector to absorb, the Board permitted the Reserve Banks to take on this new operational responsibility.

\section{Payment Services of the Reserve Banks}

C ash Services. The Reserve Banks provide coin and currency to banks on demand and receive excess coin and currency from banks; the banks' reserve accounts are debited and credited for the value of these transactions. However, Reserve Banks do not charge banks for cash services, since the Board has determined that cash services are a central bank function.

Check Clearing. The offices of Reserve Banks throughout the nation receive checks from banks for collection, and the proceeds from the collection of these checks are credited to the reserve accounts of the depositing banks. The timing of credits reflects the length of time required for the Reserve Banks to present the checks to the banks on which they are drawn (paying banks) and to receive payment, which is made by debiting the reserve accounts of the paying banks. To facilitate this process, the Reserve Banks operate a national system for transporting checks to the paying banks. Reserve Bank check-collection services include both the clearing function (receiving 


\section{CALCULATING THE FED'S SHARE}

The calculations in Tables 1-3 are based on three categories of checks processed by Federal Reserve Banks: those issued by the federal government, U.S. postal money orders, and all other checks (referred to as "commercial checks"). Commercial checks processed in the United States include "on-us" checks-checks drawn on the banks where they were first deposited. Since "on-us" checks do not have to be cleared between banks, in all three tables we have subtracted them from the totals for interbank checks processed in the United States.

For example, the figures for 1980 in Table 1 were calculated in this manner: Annual Reports of the Board of Governors include the numbers of checks processed by the Reserve Banks each year. The Annual Report for 1980 indicates that the Reserve Banks processed 15,721 million commercial checks, 705 million government checks, and 117 million postal money orders. The number for commercial checks, however, reflects double counting: Checks received by one Reserve Bank that were sent to another Reserve Bank for collection were counted as checks processed by each bank. Beginning in 1982, the Annual Reports eliminated this double counting of commercial checks. The numbers for 1982 are available with and without the double counting: The number of commercial checks processed without double counting is 94 percent of the number with double counting. Applying this 94 percent adjustment to the data for 1980 yields an estimate of 14,777.7 million commercial checks, and 15,599.7 million for total checks, including government checks and postal money orders.

The total number of commercial checks in the nation in 1980 is estimated as 42 percent of the number of commercial checks processed by the Reserve Banks. We divided the number of checks the Fed processed by the percentage of checks that it processed to arrive at the total number of commercial checks issued in the United States in 1980:

$$
14,777.7 \mathrm{~m} / .42=35,185 \text { million. }
$$

Of these 35,185 million checks, approximately 29.6 percent, or 10,414.8 million, were "on-us" checks. We subtracted the "on-us" checks from the commercial checks, then added the federal government checks and the U.S. Postal orders to arrive at the total number of interbank payment items processed in 1980:

$$
35,185 m-10,414.8 m+705 m+117 m=25,592.2 \text { million. }
$$

In Table 2, the average estimated value of a check in 1980 was $\$ 792$, and the average estimated value of an "on-us" check was $\$ 867$. Average check values in these tables are based on the values in the 1979 Atlanta Fed Check Study, adjusted for inflation and other factors. The values for checks processed by the Federal Reserve are actual, except that 1980 data have been adjusted for the double counting that was used in Federal Reserve reporting systems at that time. We multiplied the number of commercial checks by the average value per check $(35,185$ million $\times \$ 792)$ to arrive at a total value of $\$ 27.9$ trillion for checks processed in the United States in 1980 . We then subtracted the estimated value of "on-us" checks $(10,414$ million $\times \$ 867=\$ 9.0$ trillion) and added the value of federal government checks ( $\$ 599$ billion) and postal money orders ( $\$ 6$ billion) to arrive at a total value of $\$ 19.4$ trillion.

In Table 3, we divided the number of payment items that the Federal Reserve Banks processed by the total number of interbank payment items processed in the United States (as calculated in paragraph 3, above) to arrive at the Federal Reserve's share of payment-items processing for 1980:

$$
15,599.7 \text { million / 25,592.2 million }=.61 \text {, or } 61 \text { percent. }
$$


checks and presenting them to paying banks) and the settlement function (debiting and crediting reserve accounts).

Automated Clearinghouse. Banks that use the Federal Reserve's ACH service instruct Reserve Banks to pay other banks ( $\mathrm{ACH}$ credit entries) or to receive payment from other banks ( $\mathrm{ACH}$ debit entries). These entries are processed through the computer facilities of the Reserve Banks (clearing function), and entries are posted to the reserve accounts on the settlement dates designated by the banks (settlement function).

\section{Safekeeping of Definitive Securities and} Noncash Collection. Reserve Banks accept definitive securities (securities in paper form) for safekeeping. This service, however, is now largely limited to securities used to collateral ize government deposits and discount window loans. The Reserve Banks collect interest coupons and matured securities and credit the proceeds to the reserve accounts of banks that own the securities.

Wire Transfer of Funds. Banks with reserve accounts at Reserve Banks may initiate transfers of their reserves to other banks through the Fedwire funds transfer service. Fedwire is a real-time gross settlement system. Fedwire funds transfers are processed electronically and are final when accepted for processing by the Reserve Banks. A final payment is one which is unconditional and irrevocable. Clearing and settlement is virtually simultaneous. Fedwire is described as a large-value funds transfer service because it is designed to facilitate interbank funds transfers (Horii and Summers, 1994).

Wire Transfers of Securities. O wnership of United States government securities and some agency securities is recorded in the securities accounts held by the Reserve Banks. Banks can transfer ownership of these securities via the Fedwire securities transfer service, and each transfer is final when accepted by the Reserve Banks for processing.

Fiscal Agency. The Reserve Banks provide account, custodial, and payment services to the U.S. Treasury and to a variety of other government agencies. These services include issuing and redeeming U.S. Treasury securities as well as securities of other U.S. agencies.

Net Settlement. Banks that are members of private clearing organizations may decide to settle their mutual obligations through multilateral netting. If a private clearing service uses the net settlement services of the Reserve Banks, the net debit and credit positions of the private banks are settled through entries to their reserve accounts at the Reserve Banks.

\section{TRENDS IN CLEARING AND SETTLEM ENT}

The Reserve Banks' share of total interbank payments has declined since 1980 for at least three of the four principal types of payment instruments: checks, large-value funds transfers, and large-value securities transfers. Tables 1, 2 and 3 show the declining Reserve Bank components for both the volume and the value of interbank payment transactions. We have not been able to develop a time series on the share of the volume and value of $\mathrm{ACH}$ payments processed by the Reserve Banks.

\section{Check Clearing}

Table 3 indicates a significant decline in the Reserve Banks' share of interbank check clearing, in terms of both volume and value. ${ }^{9}$ Between 1980 and 1994, the Reserve Bank's component of interbank checkclearing volume declined by about onethird, from an estimated 61.0 percent to 39.3 percent, while its check-value component declined from an estimated 48.5 percent to 24.9 percent. These declines are consistent with a conventional interpretation of major changes in the interbank check clearing market, including (1) the introduction of Reserve Bank pricing for services, mandated by the MCA, (2) a fairly rapid development of alternative private-sector channels for check clearing, and (3) adoption by the Board of Governors of same-day settlement amendments to Regulation CC.

These amendments to Regulation CC, effective January 1, 1994, changed the

\footnotetext{
${ }^{9}$ Interbank check clearings are so-called "transit items," for which the payor ( check writer) and payee have accounts at different banks. These are in contrast to "on-us" checks, for which the payor and payee have accounts at the same bank.
} 


\section{Table 1}

\section{Volume of Interbank Non-Cash Transactions (in millions of transactions)}

\begin{tabular}{|c|c|c|c|c|c|c|c|c|}
\hline \multirow[b]{2}{*}{ Type of Payment } & \multicolumn{2}{|c|}{1980} & \multicolumn{2}{|c|}{1985} & \multicolumn{2}{|c|}{1990} & \multicolumn{2}{|c|}{1994} \\
\hline & FR & Total & FR & Total & FR & Total & FR & Total \\
\hline Check $^{1}$ & $15,599.7$ & $25,592.2$ & $16,687.0$ & $33,489.8$ & $19,304.0$ & $39,670.0$ & $17,149.0$ & $43,637.4$ \\
\hline $\mathrm{ACH}^{2}$ & 227.0 & -- & 585.0 & -- & $1,435.0$ & - - & $2,379.0$ & $2,521.8$ \\
\hline $\begin{array}{l}\text { Large-Value } \\
\text { Funds Transfer }\end{array}$ & 25.8 & 39.0 & 45.0 & 69.9 & 62.6 & 99.9 & 72.0 & 117.5 \\
\hline Securities Transfer ${ }^{4}$ & -- & -- & 7.7 & 7.7 & 10.9 & 12.9 & 12.6 & 19.1 \\
\hline Card & $\mathrm{N} / \mathrm{A}$ & -- & $\mathrm{N} / \mathrm{A}$ & -- & $\mathrm{N} / \mathrm{A}$ & $10,478.1$ & $\mathrm{~N} / \mathrm{A}$ & $13,681.0$ \\
\hline
\end{tabular}

Sources: Annual Reports of the Board of Governors of the Federal Reserve System and the Bank for International Settlements.

1 See Shaded Box, page 10.

2 Total ACH volume represents Federal Reserve commercial and government items plus items processed exclusively by private-sector arrangements. The figures for Federal Reserve volumes are taken from actual, recorded data. The source of the estimate for the private-sector volume is the National Automated Clearing House Association. The private ACH processors active in 1994 included the Arizona ACH, Hawaii ACH, New York ACH, and Visa ACH. Data for private ACH processors for periods before 1994 are either not available or incomplete. Note that the majority of items handled by private ACH processors are also delivered to the Federal Reserve for processing, to gain access to endpoints serviced only by the Federal Reserve. In 1994, for example, the total number of items actually originated and received by private ACH operators was estimated to be 521 million; of these, only 143 million were also delivered exclusively within the private arrangements.

3 The total volume of large-value funds transfers is the sum of Fedwire funds transfers and Clearing House Interbank Payments System (CHIPS) transfers.

4 Total number of Fedwire securities transfers plus adjusted gross volume estimates for the securities transfers of the Government Securities Clearing Corporation (GSCC) and the Participants Trust Company (PTC). The GSCC estimates were adjusted downward by subtracting the number of end-of-cycle transfers made through Fedwire, to avoid double counting. All securities transfers of the Government National Mortgage Association (GNMA) were processed through PTC; they could, however, have been processed by Fedwire, had the Federal Reserve chosen to provide such services to GNMA.

rules under which banks pay each other for checks. Before implementation of the same-day settlement provisions, a bank presented with checks directly by another private bank could either pay the collecting bank the following business day or charge the bank a fee for payment the same day. Reserve Banks, in contrast, debited the reserve accounts of paying banks the same day they delivered the checks to the banks, and the Reserve Banks did not pay fees for this privilege. W hen private correspondents complained that these rules gave the Reserve Banks an unfair advantage, the Fed adopted the same-day settlement regulation, which says that if a collecting bank presents checks to the place of business of a paying bank before 8 a.m. local time, the paying bank must return the checks or pay the collecting bank through a Fedwire funds transfer by the close of business the same day. The paying bank is not allowed to charge the collecting bank a fee for same-day settlement. Banks may waive these rules for the timing of check presentment and means of payment if they wish (Fitzgerald and Macoy, 1993; Crockett, 1994b). Reserve Bank check collection volume through September 1994 was 12 percent below the volume for the same period in 1993. This decline is attributed largely to same-day settlement (Marjanovic, 1994b).

\section{Automated Clearing House (ACH)}

The Reserve Banks are the dominant processors of $\mathrm{ACH}$ payments. They handle all government-related transactions and a 


\section{Table 2}

\section{Value of Interbank Non-Cash Transactions (in trillions of dollars)}

\begin{tabular}{|c|c|c|c|c|c|c|c|c|}
\hline \multirow[b]{2}{*}{ Type of Payment } & \multicolumn{2}{|c|}{1980} & \multicolumn{2}{|c|}{1985} & \multicolumn{2}{|c|}{1990} & \multicolumn{2}{|c|}{1994} \\
\hline & FR & Total & FR & Total & FR & Total & FR & Total \\
\hline Check ${ }^{1}$ & 9.4 & 19.4 & 10.1 & 31.9 & 13.2 & 43.5 & 12.6 & 50.6 \\
\hline $\mathrm{ACH}_{2}$ & 0.3 & -- & 2.1 & -- & 4.7 & -- & 8.4 & 9.1 \\
\hline $\begin{array}{l}\text { Large-Value } \\
\text { Funds Transfer }\end{array}$ & 47.9 & 85.0 & 109.1 & 187.5 & 199.1 & 421.1 & 211.2 & 506.6 \\
\hline Securities Transfer" & - - & -- & 74.2 & 74.5 & 99.9 & 108.1 & 144.7 & 170.0 \\
\hline Card & $N / A$ & 0.1 & $N / A$ & 0.2 & $N / A$ & 0.5 & $\mathrm{~N} / \mathrm{A}$ & 0.7 \\
\hline
\end{tabular}

Sources: Annual Reports of the Board of Governors of the Federal Reserve System and the Bank for International Settlements.

1 See Shaded Box, p. 10.

2 The value of transactions handled by the Federal Reserve plus the value of transactions handled solely by private ACH processors (see Table 1, footnote 2). For 1994, the estimated value of ACH transactions processed solely by the private sector was about $\$ 700$ billion.

3 The sum of the value of Fedwire funds transfers and Clearing House Interbank Payments System (CHIPS) transfers.

4 The sum of the value of Fedwire securities transfers, plus the value of the adjusted gross volume for the Government Securities Clearing Corporation (GSCC) plus the value of Participants Trust Company (PTC) adjusted gross volume. See Table 1, footnote 4, for more details.

\section{Table 3}

Federal Reserve Share of Interbank Non-Cash Transactions

\begin{tabular}{|c|c|c|c|c|c|c|c|c|}
\hline \multirow[b]{2}{*}{ Year } & \multicolumn{2}{|c|}{ Check } & \multicolumn{2}{|c|}{$\mathrm{ACH}$} & \multicolumn{2}{|c|}{ Large-Value Funds Transfers } & \multicolumn{2}{|c|}{ Securities Transfers } \\
\hline & $\begin{array}{l}\text { Volume } \\
\text { (percent) }\end{array}$ & $\begin{array}{l}\text { Value } \\
\text { (percent) }\end{array}$ & $\begin{array}{l}\text { Volume } \\
\text { (percent) }\end{array}$ & $\begin{array}{l}\text { Value } \\
\text { (percent) }\end{array}$ & $\begin{array}{l}\text { Volume } \\
\text { (percent) }\end{array}$ & $\begin{array}{l}\begin{array}{l}\text { Value } \\
\text { (percent) }\end{array} \\
\end{array}$ & $\begin{array}{l}\text { Volume } \\
\text { (percent) }\end{array}$ & $\begin{array}{l}\text { Value } \\
\text { (percent) }\end{array}$ \\
\hline 1980 & 61.0 & 48.5 & -- & -- & 66.2 & 56.4 & -- & -- \\
\hline 1985 & 49.8 & 31.7 & -- & - & 64.4 & 58.2 & 100 & 100 \\
\hline 1990 & 48.7 & 30.3 & - & - & 62.7 & 47.3 & 84.5 & 92.4 \\
\hline 1994 & 39.3 & 24.9 & 94.3 & 92.3 & 61.3 & 41.7 & 66.0 & 85.1 \\
\hline
\end{tabular}

large share of commercial transactions. However, their present share of the volume and value of interbank $\mathrm{ACH}$ transactions, which exceeds 90 percent, does not appear to be sustainable. In addition to the Reserve Banks, three private organizations process ACH payments: the Arizona Clearing House Exchange, the N ew York Clearing House, and Visa USA. The financial press cites the share of $\mathrm{ACH}$ payments processed by the Reserve Banks at about 80 percent, with these three organizations processing the remaining 20 percent ( $M$ arjanovic, 1995a,b). This statistic is based on the fact that these private organizations receive 20 percent of total $A C H$ entries. However, some of the $\mathrm{ACH}$ entries these private organizations receive are routed through the Reserve Banks for processing.

In this paper, the volume of $\mathrm{ACH}$ payments attributed to the Reserve Banks is that actually processed by the Reserve Banks, whether the originating institutions delivered the information on $\mathrm{ACH}$ entries to the Reserve Banks or to private processors. This method of calculating the component of $\mathrm{ACH}$ payments processed by the Reserve Banks is consistent with the 
method of calculating the component of checks processed by the Reserve Banks. For instance, checks counted as processed by the Reserve Banks include those deposited by the banks of first deposit, and by banks that serve as intermediary correspondents for the banks of first deposit.

The high Reserve Bank share can be attributed to the unique circumstances surrounding the development of the $\mathrm{ACH}$ payment mechanism, which was initially subsidized by the Reserve Banks. Significant developments in the market for $\mathrm{ACH}$ services in the last five years, relating to changes in technology, banking structure and the entry of private providers, will almost surely combine to reduce the proportion of ACH payments processed by the Reserve Banks.

\section{Large-Value Funds Transfer}

The Reserve Banks guarantee finality of funds transfers among banks over Fedwire; private banks that receive funds transfers over Fedwire do not have to be concerned that the transfers will be reversed by the Reserve Banks because of the failure of the sending banks to fund their payments through the Reserve Banks. Casual observers of the market for largevalue funds transfer might conclude that the Federal Reserve would have a virtual monopoly on this service. The information in Tables 1, 2, and 3, however, indicates that this conclusion would be incorrect. Large banks that are members of the Clearing House Interbank Payments System (CHIPS) - a wholesale wire-transfer network owned and operated by the $\mathrm{New}$ York Clearing House- use that system as an alternative to transfers over Fedwire for large-value funds transfers. M embers of CHIPS net their interbank obligations multilaterally and settle these obligations as a group at the end of the day using Fedwire funds transfers. They use CHIPS largely for settling the dollar side of foreign exchange and for other international transactions.

The component of total large-value funds transfers (over Fedwire and CHIPS) handled by Fedwire declined from 1980 to
1994. The volume component fell from 66.2 percent to 61.3 percent, and the value component fell from 56.4 percent to 41.7 percent. While the reasons for the rise in the CHIPS component of large-value funds transfers are complex, they are related in part to the rapid growth of international payments. The Reserve Banks have not considered the settlement of foreign exchange and other international transactions to be part of the mission of Fedwire, and, therefore, they have not attempted to design the Fedwire service to meet the specific funds-transfer needs of that part of the market. They have, however, responded to the market for fundstransfer services, and to new recordkeeping requirements resulting from anti-money-laundering legislation, by adopting a new format for funds transfers over Fedwire that is based on the standards of the Society of Worldwide Interbank Finance Telecommunications (SWIFT). Conversion to the new format will be completed by the end of 1997.

Another factor that may have reduced the Reserve Banks' share of large-value funds transfers is the Federal Reserve's payments system risk-reduction program, which in recent years has increased the appeal of multilateral netting for banks. The risk-reduction program, which has placed significant emphasis on containing the amount of intraday credit provided by the Reserve Banks, has probably stimulated use of alternatives to Fedwire for clearing largevalue transactions. ${ }^{10} \mathrm{O}$ the other hand, the risk controls adopted by CHIPS, which have increased the cost of funds transfers over that system, have tended to offset the effects of the Reserve Bank's risk-reduction measures.

\section{Securities Transfer}

As with funds transfer, the casual observer might conclude that the Federal Reserve has a virtual lock on the market for securities transfers. In fact, however, the Federal Reserve has restricted the range of U.S. Treasury securities and agency securities for which the Reserve Banks serve as depositories and provide 
transfer services. As a result, private systems for clearing and settling transactions involving these securities have developed. For example, the Participants Trust Company (PTC) now serves the entire market for clearing and settlement of Government National M ortgage Association (GNMA) securities.

Private-sector arrangements for netting securities transactions are also becoming more attractive to banks. The Government Securities Clearing Corporation (GSCC) has developed a multilateral netting service for future-dated U.S. government securities transactions, and it is in the process of testing an enhanced service that will support netting for same-day transactions. Introduction of this service by GSCC will likely trigger a significant further decline in the Reserve Banks' share of government and agency securities transfers. Table 3 indicates that Fedwire's share of the volume of securities transfers declined from 100 percent to 66.0 percent between 1985 and 1994. The Reserve Bank share of the value of securities transfers fell from 100 percent to 85.1 percent over the same period.

\section{Card Transactions}

As we noted earlier, the Reserve Banks do not clear payments made by cards. Table 1 shows that credit-card transactions have grown rapidly in recent years and by 1994 accounted for about 18 percent of the number of payments made by credit card, check and ACH. If payments based on other types of cards, such as debit cards and stored-value cards, grow rapidly relative to older types of payments instruments, the percentage of all retail payments processed by the Reserve Banks can be expected to continue declining.

In summary, the Reserve Banks' components of both the volume and the value of interbank payments have declined for small-value retail and large-value wholesale funds and securities transactions since about 1980. Prospective devel opments, including introduction by GSCC of multilateral netting for same-day gov- ernment securities transfers, can be expected to cause significant further reductions in the Reserve Bank component of large-value securities transfers. In addition, continued increases in the use of new types of retail (small-value) payments instruments, in which the Reserve Banks are not active, could erode further their role in the processing of retail payments generally.

\section{REASONS FOR THE RESERVE BANKS' DECLINING SHARE OF
INTERBANK PAYMENTS}

Tables 1, 2 and 3 indicate that the Reserve Banks' historically important role in providing clearing services has been declining, although it is still significant. Changes in technology and in banking structure have reduced the Reserve Banks' advantages in providing the dominant network for clearing and settlement of payments. In addition, the policies of the Board of Governors have stimulated a greater role for the private sector in clearing interbank payments.

\section{Technology}

New technology is perhaps the single most important force leading to new initiatives for processing payments in the private sector. Within the last decade or so, the costs of both computer processing and data communications have fallen dramatically. As a result, automated processing systems are now within the financial reach of individual institutions as well as private clearinghouses. At one time, $\mathrm{ACH}$ processing required large mainframe computer systems. N ow, very powerful, small, and relatively inexpensive microprocessors are able to handle large volumes of transactions. M oreover, valueadded networks offer a wealth of national and even international data communications pathways, including networks with sufficient control and security features to handle electronic payment transactions. Thus, dramatic reductions in costs have facilitated the development of alternative networks for payment processing func- 
tions that were once the primary domain of the Reserve Banks.

\section{Banking Structure}

Regional interstate banking has also reduced the advantages of the Federal Reserve in interregional check clearing. Banking concentration resulting from the rise in interstate banking has increased the proportion of transactions handled by banks as "on-us" transactions, which bypass interbank clearing and settlement channels. Further, bank holding companies have been able to organize payments clearing among their affiliated banks on a regional basis, often by establishing regional processing centers. Today, the country is experiencing a major new interstate banking movement as a result of the Riegle-N eal Interstate Banking and Branching Efficiency Act of 1994. More and more, interstate banking extends network efficiencies to private institutions throughout the country, thus eroding the Fed's interregional checkclearing advantage. ${ }^{11}$

The last 10 or 15 years have seen the formation of national clearinghouses for both paper and electronic transactions. For example, in 1991, Visa USA began offering a national $\mathrm{ACH}$ processing service. Further, the N ew York Clearing House has expressed interest in expanding the geographic scope of its $\mathrm{ACH}$ service and connecting its processing network to other private sector providers, such as Visa (Marjanovic, 1995a,b). With respect to check clearing, the National Clearing House Association, formed in 1992, arranged the clearing of an estimated 2 million checks per day in 1994 (Marjanovic, 1994a). Similarly, the Electronic Check Clearing House Organization (ECCHO) which was introduced in 1990, was clearing an estimated 1 million checks

${ }^{11}$ Berger and Humphrey (1988) conclude that nationwide interstate banking would reduce the resources used in check collection. In addition, they estimate that it would reduce the share of total checks processed by Reserve Banks by between 43 and 60 percent over a 10 -year period. per day by 1994 , on the basis of electronic cash letters (Crockett, 1994a). Banks are also active in establishing consortia to exchange retail transactions in ATM and point-of-sale networks. Formation of these private networks for clearing payments reflects, to some extent, the increased concentration of banking in recent years. A few large banking organizations now can ex- change large volumes of checks and other payment instruments directly, without relying on a processing intermediary.

\section{Federal Reserve Policy}

The Federal Reserve has strongly embraced market techniques that promote more efficient payment operations. Explicit pricing of Federal Reserve payment services, introduced by the MCA, has eliminated subsidies to banks that use Reserve Bank services. In addition, explicit pricing of intraday, reserve-account overdrafts has increased the costs of using Reserve Bank services for banks with relatively large intra-day overdrafts (Richards, 1995). Finally, the Federal Reserve Board's action in January 1994 requiring same-day check settlement helped to reduce the barriers to check clearing between private parties. Accordingly, within the last 15 years, the explicit cost of using Federal Reserve payment-processing services has been put on more comparable terms with private-sector alternatives, and artificial legal barriers to private clearing have been removed.

Federal Reserve Board policy has also limited the involvement of the Reserve Banks in the payments system by restricting the scope of their services. For instance, the Federal Reserve declined to provide services for clearing and settling credit card sales slips and book-entry transfers of GNMA securities. The limitations on the scope of Reserve Bank payment services have facilitated the development of private systems for clearing and settling payments.

\section{Outlook for Fed Payment Services}

Technology, banking structure, and Federal Reserve policy will likely continue to influence payments processing, certainly for the foreseeable future. The outcome is likely to be a continuation of the trends shown in Table 3-declines in the components of various types of interbank payments processed by the Reserve Banks. Indeed, because virtually all the factors discussed in this paper have emerged relatively recently, the trends in Table 3 could accel erate, at least for small-value payments such as checks and $\mathrm{ACH}$. 


\section{SOME IMPLICATIONS OF REDUCTIONS IN RESERVE BANK SERVICES}

Trends in the processing of payments by Reserve Banks have implications for the efficiency of the payments system and for the risk of disruptions in the operation of the payments system.

\section{Implications for Efficiency}

Subsidy for use of Reserve Bank Services. Prior to 1980, the Reserve Banks did not charge member banks explicit fees for use of their payment services. In the 1970s, the Reserve Banks may have compounded the inefficient use of resources in the payments system by subsidizing the collection of local checks through the establishment of Regional Check Processing Centers (RCPCs). Because RCPCs provided sameday check crediting to the reserve accounts of collecting banks for checks drawn upon banks located in the same area, many local check clearinghouses could not compete and closed down (Frodin, 1984). While the establishment of RCPC s may have accelerated the speed of collection, it created additional incentives for banks to use the Fed for check clearing rather than continuing direct exchanges of checks among nearby banks. ${ }^{12}$ Recent declines in the use of Fed payment services reflect more efficient use of resources resulting from the elimination of the subsidy provided by "free" Reserve Bank services.

Implications of Interstate Banking. Inefficiency in the check-collection system prior to 1914 reflected, to a large extent, the lack of nationwide banking organizations. High exchange charges and lengthy delays in check collection that resulted from arrangements to avoid exchange charges would have been reduced or eliminated by nationwide banking. ${ }^{13}$ The spread of nationwide interstate banking reduces the chances that the declining role of the Reserve Banks in payment processing will produce a return to the kind of payments system inefficiency that existed prior to the formation of the Federal Reserve. Interstate banking, however, might also lead to distortions in the pricing of payment services that would result from collusive behavior by a few large, nationwide branching organizations.

\section{Federal Reserve as Payments System Rule}

Maker. The success of innovations in improving the efficiency of the payments system requires cooperation among providers of payment services. For instance, the Fed and the banking industry agreed many years ago to encode checks with magnetic characters (the MICR line) that make it possible for banks to sort checks by machine. This innovation would have been of little value if it had been adopted by only a few banks. Another example involves the truncation of checks in the collection process: To maximize the benefits of truncation (in which the actual paper check is taken out of circulation), the first bank that handles a check would convert the paper instrument into an electronic instrument and send the payment information on the check through the collection system electronically. Such an innovation would require the cooperation of virtually all banks.

Prior to 1914, the payments system of the United States functioned without a mechanism by which banks could cooperate in adopting innovations to make interregional check collection more efficient. Clearinghouses played such a role in their local communities. There was, however, no national clearinghouse to coordinate change for the national payments system. Banks collected checks drawn on banks located in distant cities through a correspondent banking system that often routed checks to paying banks indirectly, to avoid the exchange charges of paying banks. Indirect routing of checks increased the expense and length of time in check collection. Since its formation, the Federal Reserve has functioned as the de facto national coordinator of the payments system. The role of Reserve Banks as major providers of payment services has been important in facilitating a number of improvements in the efficiency
${ }^{12}$ For a description of RCPCs and analysis of their implications for the efficiency of the payments system, see Morris (1974, 1975a,b); White and Torgerson (1974); and Viswanathan and Mayo (1975).

\footnotetext{
${ }^{13}$ Jessup (1967) reports that nonpar banks (those imposing exchange charges) tended to be located in unit banking states. This observation supports the claim that nationwide branch banking would have reduced or eliminated exchange charges.
} 


\section{SAME-DAY SETTLEMENT: RISK REDUCTION FOR COLLECTING BANKS}

Prior to the implementation of the Federal Reserve's same-day settlement regulation, banks that collected checks through correspondents generally received payment in the form of credits to their balances at correspondent banks. Under the new regulation respondent banks can send checks directly to paying banks and receive payment the same day via wire transfers of funds to their reserve accounts at Reserve Banks. Adoption of same-day settlement, therefore, gives respondent banks more options for limiting their exposure during periods of financial distress. For relatively small banks, however, the cost of collecting checks through direct presentment may exceed the risk of collecting through correspondents. The operating costs of collecting checks through direct presentment include the costs of sorting checks and arranging for couriers to present them directly to the paying banks. Even in times of financial stress in the banking industry, relatively small banks that rely on correspondents for check collection are more likely to continue using correspondent bank services than to switch their checkcollection operations to direct presentment.

\footnotetext{
${ }^{14}$ Some authors challenge the idea that actions of the Reserve Banks to eliminate nonpar banking improved the operation of the payments system. See Baxter (1983). The literature on exhange charges provides conflicting views of this subject. See Frankel (1995); Gilbert (1991); and Salop (1990). For purposes of this section, it is sufficient to argue that, given the limited power Congress granted to the Reserve Banks over the operation of the payments system, the Federal Reserve was effective in establishing clearance of checks at par as the standard for the banking industry only because of the major role of the Reserve Banks in check clearing and settlement.
}

of the payments system, including the following:

\section{Elimination of nonpar banking. ${ }^{14}$}

2. Addition of the MICR line to checks, making them readable by check-sorting machines.

\section{Creation of the automated clearing- house.}

4. Expedited processing of return items after passage of the Expedited Funds Availability Act.

5. General promotion of check imaging and electronic presentment (Marjanovic, 1996).

Will the benefits of this leadership and innovation be lost if the Reserve Banks have a substantially smaller role in the processing of payments in the future? $\mathrm{N}$ ot necessarily. Even with a smaller opera- tional role for the Reserve Banks, the Federal Reserve Board, with its broad regulatory power, can continue to promote payments system efficiency. An important example of the Board's use of this regulatory authority to promote efficiency in the check-collection system is its recent introduction of same-day settlement for checks, which took effect in January 1994. The Fed's same-day settlement regulation sets the rules under which collecting banks present checks and receive payment the same day without paying fees to paying banks. The authority for this action of the Board is derived from the Expedited Funds Availability Act of 1987, which granted the Board regulatory authority over interbank payment relationships for purposes of promoting efficiency of the payments system. Implementation of the change did not require a large operational role for the Reserve Banks; in fact, it has caused a decline in the check collection volumes of the Reserve Banks (Marjanovic, 1994b).

Increased concentration of the banking industry through interstate banking can facilitate innovation through cooperation among the banks themselves, independent of the Fed's efforts. The evidence suggests that, in the past, there were too many banks for effective cooperation. Associations of relatively small numbers of large banks, however, can work out agreements on innovations that benefit a majority of their members. For instance, the banks that formed ECCHO agreed to accept electronic transmission of information about checks as legal presentment. In March 1995, the N ew York Clearing House announced that its members had reached similar agreement (Marjanovic, 1995c). These examples illustrate innovation in the payments system through voluntary association.

Large numbers of banks are able to coordinate the clearing and settlement of payment instruments other than checks, and to adopt innovations. For example, Visa and Mastercard coordinate their payment operations for thousands of their member banks. The growth of regional ATM networks indicates that many 
bankers can work together to provide ATM services for their customers. The $\mathrm{N}$ ational Automated Clearinghouse Association (NACHA) sets rules and standards for $\mathrm{ACH}$, even though it does not itself process $\mathrm{ACH}$ payment items. Finally, there are well established institutional arrangements for setting standards for various aspects of the payments system. Thus, past experience with check collection in the United States may exaggerate somewhat the importance of the Reserve Banks as providers of payment services in facilitating innovation in the payments system.

Access to Payments Systems. When the Reserve Banks provided the dominant nationwide system for banks to clear and settle payments, access to the payments system was determined by legislation and the operating rules of the Reserve Banks. As private organizations emerge to rival the Reserve Bank's nationwide clearing and settlement arrangement, access will be determined at least in part by these private organizations. Various agencies of the government and the courts might become involved in settling disputes on the conditions under which private arrangements for clearing and settling payments may exclude some providers of payment services. ${ }^{15}$

Check C learer of Last Resort. Issues raised by the role of the Reserve Banks as check clearer of last resort have implications for both efficiency and risk. The rise in Reserve Bank check clearing during the Texas banking crisis during the second half of the 1980s and early 1990s illustrates the role of Reserve Banks as check clearer of last resort (Clair, Kolson and Robinson, 1995). When major banks headquartered in the Southwest were in serious financial trouble, respondents turned to the Fed for check collection because they did not want to suffer disruptions and possible losses resulting from the failure of their correspondents (see shaded box, page 18). Given their major role in check processing, the Reserve Banks can absorb additional check volume when circumstances disrupt other check-collection channels.
If the Reserve Banks' check collection volumes fall substantially in the future, and their capacity to clear checks is reduced accordingly, they may no longer be able to fulfill the role of check clearer of last resort. In periods of financial stress, this situation could put an extra burden of responsibility on the banking industry for ensuring the safe operation of the payments system. Banks collecting checks would need to be vigilant in managing their risk when choosing correspondents and in agreeing to forms of settlement for checks presented directly to paying institutions. In this context, the Federal Reserve's Regulation F, "Limitations on Interbank Liabilities," mandates careful management of such interbank relationships.

\section{Implications for Risk}

Does the declining role of the Reserve Banks in processing payments increase the risk of payments system disruption? The answer depends on the nature of the shocks to the payments system.

Bank Runs. Prior to the formation of the Federal Reserve System, depositor runs were the most important source of risk to banks. The Fed can deal with threats originating from depositor runs by injecting reserves into the banking system through open-market operations and discount window loans. In addition, federal deposit insurance limits the vulnerability of banks to depositor runs.

Securities Transfers. Another possible shock to the payments system would be the disruption of arrangements for transferring ownership of securities. Is it important that the Reserve Banks retain a major role in processing securities transfers in order to minimize the effects of such shocks on the payments system? Alternatively, are private arrangements for securities transfers sufficiently sound to minimize the chances of such shocks?

Parties to securities transactions must be able to trust their agents to perform as contracted. For instance, individual investors in corporate stock must trust

\footnotetext{
${ }^{15}$ See Carlton and Frankel (1995) for analysis of a court case involving a dispute over access of a bank to Visa for issuing credit cards. Carlton and Salop (1996) discuss the issue of access by firms to joint ventures in a variety of cases.
} 
their brokers to execute trades according to their orders. They must also trust that the organizations established to clear trades and settle obligations among brokers will be effective in settling trades. For investors in U.S. Treasury and agency securities, banks function as their agents by holding securities with the Reserve Banks and with private depositories. When the investors decide to sell, the banks use Fedwire or a private system to transfer ownership of the securities and settle the trades. For investors in securities transferred through privately operated systems, the risk of not receiving the securities they have paid for, and the risk of not receiving cash for securities they have sold, depends on the reliability of netting arrangements among members of the systems.

Securities transfers through private systems have not created problems for the operation of financial markets, because these systems are well designed. In addition, active oversight by authorities such as the Federal Reserve has ensured that such private arrangements have the controls and guarantees needed to make them reliable. In particular, the guidelines for operation of delivery vs. payment systems that were released by the Federal Reserve Board on June 15, 1989, refer to various controls, including liquidity safeguards, credit safeguards, and open-settlement accounting.

As long as the private systems for securities transfers are appropriately supervised and maintain adequate risk controls, the migration of securities transfers from the Reserve Banks to private systems would not appear to create problems for the operation of financial markets. The following sections indicate, however, why the Fedwire service for transferring funds and securities remains essential for the settlement of obligations among members of these private systems. These sections also discuss the limited authority of the Federal Reserve over the operations of private clearing organizations which is derived from the role of the Reserve Banks in providing settlement services.

\section{Settlement U sing Liabilities of Private Banks: Moral Hazard and Systemic Risk.} Another source of shock to the U.S. payments system could result from the failure of a major bank used for settlement by a significant number of other banks. Prior to 1914 , banks settled payment obligations among themselves by transferring ownership of deposit liabilities at private banks, and major disruptions occurred when customers lost confidence in the nation's money center banks. Given the declining role of the Reserve Banks in processing payments, the future might bring increased public reliance on a few large banks for settling payment obligations. If it does, the government might need to ensure the survival of those banks, to prevent disruption of the payments system. This reliance on a few large banks at the heart of the payments system could amplify any moral hazard in bank supervision and regulation. Since the failure of the bank would be too disruptive to the payments system, participants in the financial system could assume that there would be little risk in transactions with those banks, including the purchase of their short-term liabilities.

\section{Multilateral Clearing Arrangements and Systemic Risk. Systems for clearing pay-} ments among banks can be designed to avoid the moral hazard outlined above. Consider, for instance, the design of CHIPS. Federal Reserve policies that apply to the operation of private large-dollar funds-transfer systems such as CHIPS include the requirement that such systems have means to ensure settlement in the event of a default by a major participant. Since these arrangements would prevent major disruptions in the payments system in the event of the failure of a particular bank, investors in bank equities and liabilities cannot assume that any one bank is essential to the operation of the payments system.

We argue that the Reserve Banks must continue to offer Fedwire services to facilitate access to reserve accounts and especially, to ensure the integrity of net settle- 
ment arrangements. Banks that use the net settlement services of Reserve Banks in their transactions with private paymentsclearing systems must have a mechanism like Fedwire for transferring reserves, to cover their net debit positions. At times, these banks must borrow reserves from each other to cover their net debits. Fedwire enables them to transfer securities electronically, both to provide collateral to lenders, and to post collateral with Reserve Banks for discount window borrowing.

Authority of the Federal Reserve over the operations of private clearing organizations rests principally on the role of the Reserve Banks as providers of settlement services, since the Fed has no statutory authority for central bank oversight of private clearing organizations. As a service provider, the Federal Reserve can make safe-and-sound operation of clearing organizations a condition to their using its interbank settlement services. The Board stated its standards for the operation of private clearing organizations in December 1994, in a policy statement titled "Privately-O perated Large-Dollar Multilateral N etting Systems." The threat of discontinuing its settlement support for such clearing organizations, however, is a very blunt supervisory instrument. For example, the Fed could disrupt clearinghouse operations, and therefore the payments system, by withdrawing its settlement services. The simple fact that the Fed could itself trigger an immediate operational crisis by withdrawing support for settlement calls into question the Federal Reserve's willingness ever to invoke such a harsh action.

The trends in the U.S. dollar payments system described in this paper indicate a major shift toward greater reliance on private arrangements for clearing both smalldollar and large-dollar payments. Increased privatization of the U.S. dollar payments system and a concomitant decline in the operational role of the Federal Reserve Banks raise questions about the adequacy of the Federal Reserve's supervisory authority to fulfill the original Congressional mandate for ensuring the stability of the nation's payments system. In fact, the Federal Reserve appears to be somewhat unusual among central banks in that it does not have explicit statutory powers related to the supervision of clearing organizations. Some of the private clearing organizations have implemented new risk controls to ensure settlement in the event of default by any of their members. These actions indicate some of the Fed's regulatory clout under current limitations on its statutory authority. It is unclear, however, whether the Fed's indirect influence on private clearing organizations through its role as provider of settlement services will be sufficient to ensure the safety and soundness of the payments system in the future.

\section{CONCLUSIONS}

The Federal Reserve Banks' role in processing payments-in terms of both volume and value- has declined since 1980, when Congress enacted legislation requiring the Reserve Banks to charge for their payment services. This decline can be expected to continue or even accelerate in the future. While the declines in the shares of payments processed by the Reserve Banks following pricing of the services represent a more efficient use of payments system resources, the declining role of the Federal Reserve Banks in payments processing has other important implications for the efficiency and stability of the payments system.

One of these implications relates to innovation. In the past, the actions of the Reserve Banks to foster innovation in the payments system relied on the status of the Reserve Banks as major providers of payment services. Will the Reserve Banks' declining role in payments processing eliminate the Fed's leadership in innovation? N ot necessarily. The Federal Reserve Board has broad authority to promote safe and efficient payment methods undertaken bilaterally between depository institutions, especially in the check-collection system. This authority is independent of the Reserve Banks' operating role in the payments system. In addition, the growing concentration of the banking industry through interstate banking is facilitating 
innovation by cooperating groups of banks that would have been more difficult when there were many more separate banking organizations.

At the same time, the growth of private payment networks raises some important new issues with respect to competition. In the past, access to the payments system was determined largely by law and by Federal Reserve policies; now some of the issues involving access to the new private payments arrangements will be settled in the courts.

Does the declining role of Reserve Banks in processing payments increase the risk of disruption in the operation of the payments system? The answer depends on how banks in bilateral and multilateral private clearing arrangements settle their obligations. Settlement through debits and credits to accounts at private banks would make the system vulnerable to disruption in the event of sudden failure by banks that provide settlement services. Fortunately, the settlement services of the Reserve Banks can limit this risk - to banks, and to the Federal Reserve in its role as lender of last resort. To facilitate the use of reserves for interbank settlement, whether net or gross, Reserve Banks should continue offering Fedwire funds and securities transfer services and net settlement services. The Federal Reserve System is able to influence the practices of clearinghouses primarily by setting conditions for their use of the settlement services of the Reserve Banks. The Fed does not have statutory authority to act as the supervisor of clearing organizations. It is not clear at this time whether the Fed's limited influence over clearing organizations will be adequate to maintain the safety and soundness of the payments system as the share of payments cleared through private channels continues to rise.

\section{REFEREN CES}

Andrew, A. Piatt. "Substitutes for Cash in the Panic of 1907," Quarterly Joumal of Economics (August 1908). Reprinted in 0. M. Sprague, History of Crises under the National Banking System, U.S. National Monetary Commission, Senate Document No. 538, 61 Congress, 2nd Session, Government Printing Office, 1910, pp. 434-59.
Baxter, William F. "Bank Interchange of Transactional Paper: Legal and Economic Perspectives," Journal of Law and Economics (October 1983), pp. 541-88.

Berger, Allen N., and David B. Humphrey. "Interstate Banking and the Payments System," Journal of Financial Services Research (1988), pp. 131-45.

Blommestein, Hans J., and Bruce J. Summers. "Banking and the Payment System," in The Payment System: Design, Management, and Supervision, Bruce J. Summers, ed. International Monetary Fund, 1994, pp. 15-28.

Brimmer, Andrew F. "Bank Credit Cards and Check-Credit Plans: Development and Implications." Remarks presented to a Joint Luncheon of Commercial Bankers and the Board of Directors of the Federal Reserve Bank of San Francisco, August 3, 1967.

Carlton, Dennis W., and Alan S. Frankel. "Antitrust and Payment Technologies," this Review (November/ December 1995), pp. 41-54.

Carlton, Dennis W., and Steven C. Salop. "You Keep on Knocking but You Can't Come In: Evaluating Restrictions on Access to Input Joint Ventures," Harvard Joumal of Law and Technology (Summer 1996), pp. 1-34,

Clair, Robert T., Joanna 0. Kolson, and Kenneth J. Robinson. "The Texas Banking Crisis and the Payments System," Economic Review, Federal Reserve Bank of Dallas (First Quarter 1995), pp. 13-21.

Crockett, Barton. "Electronic Bad-Check Notices for Corporations Expected Soon," The American Banker (January 6, 1994a), p. 17.

"Fast Clearing Off to Slow Start, Poll Finds," The American Banker (May 12, 1994b), p. 18.

Dewald, William G. "The National Monetary Commission: A Look Back," Journal of Money, Credit and Banking (November 1972), pp. 930-56.

Dwyer, Gerald P., Jr., and R. Alton Gilbert. "Bank Runs and Private Remedies," this Review (Mayl June 1989), pp. 43-61.

Economides, Nicholas, and Lawrence J. White. "Networks and Compatibility: Implications for Antitrust," European Economic Review (1994), pp. 651-62.

"Federal Reserve in the Payments System," 7-145.1. Federal Reserve Regulatory Service, $7 \bullet 48$.

"Federal Reserve System Guidelines for the Provision of Financial Services," 7-191. Federal Resenve Regulatory Service, 7•51.

Fitzergerald, Robert M., and lan W. Macoy. "Check.Processing Rule Means Efficiency, Competition," The American Banker (July 7, 1993), p. 17.

Frankel, Alan S. "Monopoly and Competition in the Supply of Money and Payment Services." Memorandum, November 1995.

Frodin, Joanna H. "Fed Pricing and the Check Collection Business: The Private Sector Response," Business Review, Federal Reserve Bank of Philadelphia (January/ February 1984), pp. 13-22. 
Gilbert, R. Alton. "Utilization of Federal Reserve Bank Services by Member Banks: Implications for the Costs and Benefits of Membership," this Review (August 1977), pp. 2-15.

Gilbert, Richard J. "On the Delegation of Pricing Authority in Shared Automatic Teller Machine Networks," in Electronic Services Networks: A Business and Public Policy Challenge, Margaret E. Guerin-Calvert and Steven S. Wildman, eds., Praeger Publishing, 1991, pp. 11544 .

Horii, Akinari, and Bruce J. Summers. "Large-Value Transfer Systems," in The Payment System: Design, Management, and Supervision, Bruce J. Summers ed., Intermational Monetary Fund, 1994, pp. 73-88.

Jessup, Paul F. The Theory and Practice of Nonpar Banking, Northwestern University Press, 1967.

Juncker, George R., Bruce J. Summers and Florence M. Young. "A Primer on the Settlement of Payments in the United States," Federal Reserve Bulletin (November 1991), pp. 847-58.

Katz, Michael L., and Carl Shapiro. "Systems Competition and Network Effects," Joumal of Economic Perspectives (Spring 1994), pp. 93-115.

Marjanovic, Steven. "The Fed Buys Banctec Check-Image Storage System," The American Banker (February 1, 1996), p. 18.

. "Arizona Clearing House Chief Eyes Expansion," The American Banker (August 18, 1995a), p. 16.

. "Chemical Joins ACH That Is Taking On the Fed," The American Banker (January 25, 1995b), p. 14.

. "N.Y. Clearing House Sets Deadline for Electronic Presentment," The American Banker (March 23, 1995c), p.1. . "PEOPLE IN THE NEWS: Clearing House Group Names President," The American Banker (November 15, 1994a), p. 18.

. _. _ . . "Citi, 4 Other J oin Clearing House Group," The American Banker (December 7, 1994b), p. 16.

Morris, Russell D. "The Fed's Regional Check Processing Performance: What Does it Imply for Electronic Funds Transfer?" Joumal of Bank Research (Summer 1974), pp. 86-91.

_. _ _ . "The Fed's RCPC Performance: A Reply," Joumal of Bank Research (Winter 1975a), pp. 257-59. pp. 72.73

"A Response," Journal of Bank Research (Spring 1975b),

Richards, Heidi Willmann. "Daylight Overdraft Fees and the Federal Reserve's Payment System Risk Policy," Federal Reserve Bulletin (December 1995), pp. 1065-1077.

Roberds, William. "Financial Crises and The Payments System: Lessons from the National Banking Era," Economic Review, Federal Reserve Bank of Atlanta (September/ October 1995), pp. 15-31.

Salop, Steven C. "Deregulating Self-Regulated Shared ATM Networks," Economics of Innovation and New Technology, (1990), pp. 85-96.
Spahr, Walter E. The Clearing and Collection of Checks, The Bankers Publishing Co., 1926.

Sprague, 0.M. History of Crises under the National Banking System, U.S. National Monetary Commission, Senate Document No. 538, 61 Cong. 2 Sess, Government Printing Office, 1910.

Summers, Bruce J. "Risk Management in National Payment Systems," in The New Financial Landscape: Forces Shaping the Revolution in Banking, Risk Management and Capital Markets, OECD (1995), pp. 253-280.

Veale, John M., and Robert W. Price. "Payment System Float and Float Management," in The Payment System: Design, Management, and Supervision, Bruce J. Summers, ed., International Monetary Fund, 1994, pp. 145-63.

Viswanathan, P., and Cesar Mayo. "A Note on 'The Fed's RCPC Performance,'" Journal of Bank Research (Spring 1975), pp. 70-71.

Watkins, Leonard L. Bankers' Balances, A.W. Shaw Company, 1929.

White, Eugene N. The Regulation and Reform of the American Banking System, 1900-1929. Princeton University Press, 1983.

White, Hubert D., and David A. Torgerson. "A Comment on 'The Fed's Performance: What Does it Imply for EFTS?'" Journal of Bank Research (Autumn 1974), pp. 193-96. 


\section{PAYMENT SERVICES OF THE FEDERAL RESERVE BANKS}

\section{Cash Services}

The Reserve Banks have a government monopoly on issuing currency, which they process for banks. They also process coin issued by the United States Mint. Reserve Banks process cash deposits and shipments without charge to banks, at least for a certain basic level of service, since this is considered a government function. In accepting deposits of currency and meeting orders for currency, the Reserve Banks maintain the quality and the integrity of the currency stock. They employ sophisticated processing equipment that separates currency fit for circulation from unfit currency, which is destroyed. Reserve Banks also identify counterfeit notes, relying on the anti-counterfeiting features built into the design of the official currency.

\section{Check Clearing}

Since their formation, the Reserve Banks have provided a nationwide check clearing service. Check processing now takes place at 11 of the 12 Reserve Bank head offices, 24 of the 25 branches, 11 regional check-processing centers (RCPCs), and one additional facility. The Reserve Banks cooperate in managing this system in a highly-integrated manner and share some facilities and mechanisms,

${ }^{16}$ Cash letters are bundles of checks accompanied by registers that list the contents of the bundles and the total value of the items they contain. These bundles are called "cash letters" because settlement for the checks is in cash-equivalent funds, subject to the rules goveming the return of checks.

${ }^{17}$ For a discussion of how float arises, is controlled, and what it costs, see Veale and Price (1994). including a national transportation system for transporting checks.

Each Federal Reserve check-processing office serves an official territory, which is designated by routing numbers encoded at the bottom of checks. A territory may include a small but highly concentrated area, such as a city, or a larger area with banks dispersed across a large region. Routing numbers are the de facto national standard for check-clearing territories throughout the United States.
The Reserve Banks accept for collection checks (cash letters) drawn on banks located within the same territory, as well as checks drawn on banks located in other Federal Reserve territories. ${ }^{16}$ The high degree of cooperation among the Reserve Banks in processing interterritory checks, and especially in debiting and crediting reserve accounts of banks located throughout the nation, facilitates an efficient nationwide check-clearing and settlement system.

The Reserve Banks accept shipments of checks in various degrees of sorting, including unsorted, sorted by Federal Reserve territory, or sorted by the banks on which the checks are drawn. Since sorting checks by territories or by the banks on which they are drawn is costly, the banks that send checks to the Reserve Banks al ready sorted are charged less than the banks that send checks unsorted and rely on the Federal Reserve Banks to sort them.

Like correspondent banks, Reserve Banks credit the accounts of the depositors of checks according to published availability schedules. That is, the depositors are able to count on receiving credit for checks drawn on banks located in different Federal Reserve territories according to a published time schedule, regardless of the Federal Reserve's ability to present the items within that schedule. Any float that results from mismatching the time of crediting the accounts of the depositing banks and the time of presentment to and debiting the accounts of paying banks is a cost of doing business for the Federal Reserve. Float is factored into the base costs recovered through explicit fees. ${ }^{17}$

In recent years, the Reserve Banks have provided a variety of value-added check-clearing services, particularly electronic information services demanded by check-clearing customers. Banks that receive cash letters (bundles of checks written by depositors) from the Reserve 
Banks can receive electronic transmissions that show the account numbers and dollar values of individual checks, information that normally would be physically presented later in the day. Timely availability of this information greatly aids banks in offering cash-management services to their large corporate customers.

In addition, the Reserve Banks are beginning to offer electronic check-deposit and presentment services, as well as truncation services, for banks that elect to settle checks in this manner. Reserve Banks recently have begun to offer imageprocessing services both to commercial banks and to the U.S. government. For example, images of government checks are captured and stored in archives, facilitating federal government investigations and claims settlements that involve payment by check. In addition, commercial image services are now being provided to banks, especially services designed to expedite check adjustments and returns.

\section{Automated Clearinghouse}

The automated clearinghouse $(\mathrm{ACH})$ is an electronic alternative to check processing. In fact, the $\mathrm{ACH}$ was originally most attractive as a means of converting payroll disbursement and other recurring money transfers from check-based transactions to electronic transactions. The ACH is both a credit and a debit payment mechanism; that is, customer banks can make payments and withdrawals from accounts within the system. Use of $\mathrm{ACH}$ debit entries increases the efficiency and speed of transactions such as insurance premiums and mortgage payments, and they facilitate the concentration of cash by treasurers of businesses that maintain demand deposit accounts at large numbers of banks.

The Reserve Banks began providing ACH services to the United States Treasury and commercial banks in 1972. The federal government was a pioneer in converting its own paper-based check payments to $\mathrm{ACH}$. At its inception, $\mathrm{ACH}$ processing required a very significant investment in computer technology. Only a large organization like the Federal Reserve System, with its established technical infrastructure and its extensive access to capital, was in a position to invest in a venture of this magnitude, for which the return was still uncertain. Moreover, the volume of payments at ACH's inception was not sufficient to justify the costs of the large initial investment for most companies. An exception was the New York Clearing House, which chose to handle the processing for ACH transactions in the Second Federal Reserve District. Over the years, the Arizona Clearing House and Visa USA, Inc. have also established successful ACH processing operations. The Chicago Clearing House also attempted to offer an $\mathrm{ACH}$ processing service but discontinued its service after a few years.

\section{Safekeeping of Definitive Securities and Non-cash Collection}

The Reserve Banks continue to provide definitive safekeeping and noncash collection services to depository institutions, but on a significantly reduced scale in comparison to earlier years. ${ }^{18}$ Definitive securities are paper instruments, such as bonds issued by state and local governments. Safekeeping for such securities includes accepting them under a trust agreement, collecting interest coupons, and redeeming matured securities. Today, only three Federal Reserve offices provide these services as priced services, although they do so for depository institutions located throughout the United States. Each Federal Reserve Bank does safekeep securities it accepts as collateral for discount window loans and/or in its role as fiscal agent. The demand for such services eventually will disappear completely as all securities are converted from paper to book-entry form, with ownership recorded and transferred electronically in the records of depositories.

\section{Wire Transfer of Funds and Securities \\ Banks can transfer reserves among themselves electronically through the Fedwire funds transfer service. This is a}

\footnotetext{
${ }^{18}$ Non-cash items are handled on a collection basis, meaning that principle and interest are credited to the accounts of banks with securities in safekeeping when collected, not on the basis of a published availability schedule.
} 
real-time gross settlement service that provides final payment. Each transfer is processed separately without a netting of payment messages among banks (gross settlement), and the transfer of funds is final, which means that it cannot be reversed. If a bank sends a payment message over Fedwire and later fails while its reserve account is overdrawn, the Reserve Bank holding the overdrawn reserve account cannot recover funds from the receiver of the payment message. The finality of Fedwire funds transfers make them a unique type of payment, quite distinct from other payment services provided by the Reserve Banks. For instance, the Reserve Banks do not guarantee that credits to reserve accounts resulting from check collection are "good funds." If a Reserve Bank cannot collect from a bank on which the checks have been drawn, it has the right to reverse the credits to the reserve account of the depositing bank. Fedwire funds transfer is a natural monopoly, in that only the Federal Reserve can provide final settlement of reserves transfers.

Reserve Banks began providing the Fedwire funds transfer service in 1918 via telegraph. Today the Reserve Banks operate a highly-sophisticated computer network with more than 8,000 on-line connections to the Fedwire funds transfer system. The Fedwire securities transfer service dates to 1967, when the Reserve Banks agreed with the United States Treasury to begin converting U.S. Government securities to book-entry form. The computer system of the Reserve Banks became the depository for ownership of the government securities. The Fedwire securities transfer service is also a realtime gross settlement service, providing for the simultaneous delivery of securities and payment in final funds on the books of the Reserve Banks. ${ }^{19}$ This delivery-versuspayment feature of securities transfers over Fedwire limits the risk to participants in the market for government securities, because a seller of securities can transfer ownership to a counterparty in a transaction without concern about whether the counterparty will pay for the securities. Since the Reserve Banks assume any risk from the transfer of reserves over Fedwire, the Fedwire funds transfer service is, together with federal deposit insurance and the discount window, part of the federal safety net for the banking system. It's important to note that, given the high volume, value, and velocity of wire transfers, the Fedwire service is able to operate efficiently as a real-time gross settlement system only because the banks that use Fedwire have access to significant amounts of intraday credit from the Reserve Banks. When the Reserve Banks agree to process Fedwire funds transfers on behalf of financially troubled institutions, they essentially guarantee payments by these institutions, thereby providing confidence to counterparties receiving the payments and contributing to the stability of the payments system. The Reserve Banks manage the risk in providing this guarantee through a combination of operational and financial controls.

An important milestone in the Fedwire funds and securities transfer services was the introduction of explicit pricing of Federal Reserve intraday overdrafts on April 14,1993 , to provide banks an incentive to limit their use of intraday credit (Richards, 1995; Summers, 1995).

\section{Fiscal Agency}

One of the roles of the Federal Reserve Banks is to serve as a fiscal agent for the U.S. government. The Reserve Banks provide services to the United States Treasury and to a variety of other government agencies, as requested by the Treasury Department. For example, they collect checks, process ACH transactions, and make wire transfers on behalf of the fiscal principals. They provide a variety of cash management services for government agencies, including collection, cash concentration, and letters of credit. In addition, they service the public debt and, through the Fedwire securities transfer service, provide operational support for the secondary market in U.S. government and agency securities. Approximately 12 
percent of the annual operating expense of the twelve Reserve Banks is attributable directly to their role as fiscal agents (Federal Reserve Planning and Control System).

\section{Net Settlement}

N et settlement is a service provided by the Federal Reserve Banks to a group of banks that clear payments among themselves, net their interbank positions, and settle their net debit and credit positions through entries to their reserve accounts. These arrangements can be classified as "final" or "provisional." N et settlement entries classified as final are not reversible by the Reserve Banks, whereas provisional entries are reversible.

In December of 1994, the Board of Governors of the Federal Reserve System issued a policy statement governing largevalue arrangements, which establishes the conditions that such arrangements must meet to operate and to gain access to Federal Reserve net settlement services. ${ }^{20}$ Large-value settlement arrangements include electronic funds transfers (for example, the Clearing House Interbank Payments System or CHIPS) and electronic securities clearing and settlement (for example, the Government Securities Clearing Corporation or GSCC). To minimize the systemic risk associated with large-value netting arrangements, the new policy statement requires that these arrangements be designed to achieve final settlement. Members use Fedwire to settle their net debit obligations resulting from net settlement. Also, one private ACH service and one check-clearing arrangement use Fedwire for net settlement.

The Reserve Banks also provide settlement services for small-value payments to approximately 160 local and regional clearinghouses throughout the country. The small-dollar settlements are for a variety of netting arrangements, predominantly check clearinghouses, but al so for credit card systems and ATM and POS networks. Settlements for these netting arrangements are provisional. The Federal Reserve does not guarantee that credits to reserve accounts resulting from use of its provisional net settlement service represent "good funds." If a Reserve Bank is not able to collect the net debits from members of a group, it may reverse the entries made to the reserve accounts for the net settlement.

One reason depository institutions have a strong interest in using the Federal Reserve for interbank settlement is that virtually all depository institutions in the United States hold reserve accounts at the Reserve Banks (Blommestein and Summers, 1994). They are uniquely positioned to meet the needs of clearinghouses with a diverse membership, since virtually all the clearinghouse members would hold accounts with the Reserve Banks. In addition, the Reserve Banks are able to offer their natural monopoly advantage of providing final settlement in central bank money, rather than in terms of the liabilities of another private bank.

\footnotetext{
${ }^{20}$ Federal Reserve Press Release, December 21, 1994, Docket No. R-0842.
} 